\title{
The (Re)newed Barrier to Access to Medication: Data Exclusivity
}

Srividhya Ragavan

Texas A\&M University School of Law, ragavan.sri@law.tamu.edu

Follow this and additional works at: https://scholarship.law.tamu.edu/facscholar

Part of the Food and Drug Law Commons, and the Legislation Commons

\section{Recommended Citation}

Srividhya Ragavan, The (Re)newed Barrier to Access to Medication: Data Exclusivity, 51 Akron L. Rev. 1163 (2018).

Available at: https://scholarship.law.tamu.edu/facscholar/1260

This Article is brought to you for free and open access by Texas A\&M Law Scholarship. It has been accepted for inclusion in Faculty Scholarship by an authorized administrator of Texas A\&M Law Scholarship. For more information, please contact aretteen@law.tamu.edu. 


\title{
THE (RE)NEWED BARRIER TO ACCESS TO MEDICATION: DATA EXCLUSIVITY
}

\author{
Srividhya Ragavan*
}

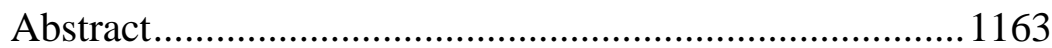

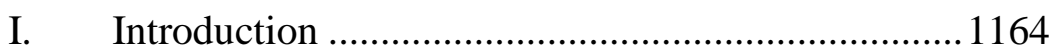

II. Data Exclusivity: Definition \& Debate .....................1167

III. Historic Origin \& International Obligations of Data Exclusivity .................................................................. 1170

A. Protection Against Unfair Competition ...............1171

B. Protection of "Undisclosed Information" as Outlined in Paragraph 2 of Article 39...............1172

C. Protection for "Data Submitted to Governments or Governmental Agencies" as Outlined in Article 39.3 .....................................1173

IV. Courses of Action for Developing Countries ...........1175

A. Defining “Undisclosed” Test Data.......................1176

B. "Undisclosed" to Whom? ....................................1177

C. What Amounts to "Unfair Commercial Use?".1178

D. What is a New Chemical Entity? ........................1181

E. "Known” Chemical Entities................................1183

F. Does New Chemical Entity Include Biologics? ...........................................................1185

G. Reliability of Clinical Trial Information from Other Countries ................................................1187

H. Should Exclusivity be Relaxed when National Markets are Not Being Supplied? ......................1190

I. Data Exclusivity \& Patent Linkage.......................1191

IV. Conclusion ....................................................................1195

\section{ABSTRACT}

This Article is set in the background of the consequences of the WTO's prescriptions on patenting of life-saving medications which has 
largely contributed to the morphing of patents on life-saving medication into a luxury. Remarkably, there has been a transformation of the role of patents in the context of pharmaceutical innovation into a strategic business tool leading to a larger interest in creation and sustenance of regulatory rights. The biggest global development in this area is an increased effort to strengthen exclusivity using regulatory protections for all chemicals, and even, biologics, involved in all stages of drug development. Consequently, pharmaceutical companies have expertly navigated this confluence of patents with regulatory data protection to leverage themselves in a manner effectively creating high protection and financial rewards for what materials that could otherwise be susceptible for generic competition. This Article concerns itself with the regulatory regime that effectively provides for exclusivity of clinical trial data. The focus of the Article will be on how and why data exclusivity works for the pharmaceutical industry to promote and/or protect market exclusivity globally. Thus, the Article examines what data exclusivity is, the international trade obligations relating to providing data exclusivity, and the impact of the data exclusivity obligations on access to medication issues, with a specific focus on developing countries while keeping the U.S. regime as the vantage point to examine these issues. The Article outlines how the data exclusivity regime can operate in parallel with the patent regime to add a layer of protection for the data, thus adding to the protection regime for chemical or biologic data. In doing so, this Article will address some of the more controversial issues that have arisen globally with reference to data exclusivity within the larger access to medication debate.

\section{INTRODUCTION}

The year 2017 marks another step closer to the 25th anniversary of the establishment of the World Trade Organization (WTO). ${ }^{1}$ In the area of intellectual property rights, particularly patents, one significant phenomenon of the first quarter-century of the establishment of the WTO is the morphing of patents on life-saving medication into a luxury. The WTO's global patent prescription largely helped establish economic

\footnotetext{
* Srividhya Ragavan is a Professor of Law at the Texas A\&M University School of Law specializing in international trade and intellectual property issues. The author wishes to extend thanks and appreciation to Ms. Priyanka Sunjay, National Law University, Jodhpur, India for providing excellent research for this Article.

1. Marrakesh Agreement Establishing the World Trade Organization, Apr. 15, 1994, 1867 U.N.T.S. 154; see also The WTO, WORLD TRADE ORG. (Mar. 2, 2018), https://www.wto.org/ english/thewto_e/thewto_e.htm [https://perma.cc/7QKV-KYAU].
} 
status as the marker distinguishing those that can access life-saving medication from the rest of the population. Consequently, this decade witnessed an elevated interest over the role of patents in the context of pharmaceutical innovation. While patents continued to be an important strategic business tool, there was a slow but a steady downgrading of patents from its touted original position of being the unique economic prescription to promote innovation. As such, the rhetoric of innovation, which long served as a platform to nestle "patents," was being challenged in many industries and in many countries. From the United States - the traditional flag-holder touting the benefits of patents - to developing countries such as India — which is a relatively newer graduate of the trade regime $^{2}$ - the role of patents have come up for scrutiny. People generally perceived patents, however unfairly, as the woe affecting pricing and thus thwarting access to life-saving medication. While pricing was one of the several questions that resulted in the permeation of pharmaceutical pricing as an election issue in the United States, globally, pricing as well as other policies became the subject of a larger access to medication debate. ${ }^{3}$

In the United States, the Supreme Court's decision highlighting the low thresholds of biotechnology patents came at a time when academic focus underscored how secondary patents potentially blocked downstream innovations. ${ }^{4}$ At a global level, international organizations

2. See, e.g., Srividhya Ragavan, Of the Inequals of Uruguay, 10 MARQ. INTELL. PROP. L. REV. 274 (2006) (detailing India's process patent regime and its graduation into the TRIPS patent regime).

3. In 2016, as the debate on the price of pharmaceuticals became one of the important election issues in the United States, other issues that contribute to such an increase in price, such as patents, came into the limelight. For example, in January of 2016, the U.S. News reported that 50 Democratic members of the House, led by Rep. Lloyd Doggett, D-Texas, urged government agencies to consider diluting or diminishing the exclusive rights over patents on pharmaceuticals. See Kimberly Leonard, Can the Government Already Control Drug Prices, U.S. NEWS (Jan. 11, 2016), http://www.usnews.com/news/articles/2016/01/11/congressional-democrats-urge-nih-to-act-ondrug-prices. Similarly, in 2016, Senator Bernie Sanders and Representative Elijah Cummings sought more information about the price increases for Iclusig, a drug used to treat chronic myeloid leukemia which was priced at $\$ 199,000$ for a year's worth of treatment. See Sanders, Cummings Send Letter on ARIAD's Staggering Price Increases, (Oct. 20, 2016), https://www.sanders.senate.gov/newsroom/press-releases/sanders-cummings-send-letter-on-ariadsstaggering-price-increases [https://perma.cc/CBY3-VJKG].

4. See, e.g., Thomas Faunce \& Joel Lexchin, 'Linkage' Pharmaceutical Evergreening in Canada and Australia, AustL. AND N. Z. HEALth POL’y (Biomed Central) (June 1, 2007); see also Amy Kapczynski, Chan Park \& Bhaven Sampat, Polymorphs and Prodrugs and Salts (Oh My!): An Empirical Analysis of "Secondary" Pharmaceutical Patents, PLOS ONE (Dec. 5, 2012), http://journals.plos.org/plosone/article/file?id=10.1371/journal.pone.0049470\&type=printable [https://perma.cc/5VBM-FLDL]; Amy Kapczynski, Engineered in India: Patent Law 2.0, 8 NEW ENG. J. MED. 497, 497-99 (Aug. 8, 2013); Scott Hemphill \& Bhaven Sampat, When Do Generics Challenge Drug Patents?, J. EMPIRICAL LEGAL STUD., 613, 613-49 (2011); Scott Hemphill \& Bhaven 
affirmatively asserted that patents had transformed into a barrier to promote global access to medication. ${ }^{5}$ Further, nationally as well as globally there was a marked increase in active participation by nongovernmental organizations as well as the public. For example, in September 2017, a protest against the 1,157\% price-increase by Eli Lilly on diabetes drugs such as Humalog, whose patent had expired 75 years ago, made the headlines, prompting protests outside the Eli Lilly headquarters. ${ }^{6}$ Overall, the effort to ensure accessibility and affordability of pharmaceuticals resulted in the focus on patents broadening to an extended consideration of related tools such as pricing, regulatory details, innovation, and more. Consequently, on the one hand, the pharmaceutical industry assumed a defensive posture denouncing reduction in patent exclusivity as stifling innovation; on the other hand, the pharmaceutical industry scrambled for tools and strategies to consolidate its exclusivity.

This Article will examine one such tool, being data exclusivity, which has traditionally helped the pharmaceutical industry consolidate its market exclusivity. ${ }^{7}$ The focus of the Article is on how and why data exclusivity works for the pharmaceutical industry to promote and/or protect market exclusivity globally. Thus, the Article examines what data

Sampat, Evergreening, Patent Challenges, and Effective Market life in Pharmaceuticals, $31 \mathrm{~J}$. HEALTH ECON. 327, 327-39 (2012).

5. See The United Nations Secretary-General's High-Level Panel Report on Access to Medicines Report, UNITED NATIONS (Sept. 2016), http://www.unsgaccessmeds.org/final-report/ [https://perma.cc/JH7Y-CMZH] [hereinafter Report of United Nations]. A similar report issued by the World Health Organization (WHO) relating to Hepatitis C treatment in lower income countries highlighted a series of strategies involving generic medicines, licensing models, local production, and differential pricing as being critical to enable lifesaving; see also Over 1 Million Treated with Highly Effective Hepatitis C Medicines, World Health ORg. (Oct. 27, 2016), http://www.who.int/mediacentre/news/releases/2016/hepatitis-c-medicines/en/

[https://perma.cc/96LN-ZTCM]. This report highlights that "[l]icensing agreements and local production in some countries have gone a long way to make these treatments more affordable.” Dr Suzanne Hill, WHO Director for Essential Medicines and Health Products, has asserted the importance of local production and pricing models to make medication accessible and affordable. Id. See also Ed Silverman, Hepatitis C Drugs Remain Unaffordable in many Countries, PHARMALOT (May 31, 2016), https://www.statnews.com/pharmalot/2016/05/31/gilead-hepatitis-drug-prices-who/ [https://perma.cc/Z2A4-ABA7]. See generally Development Agenda for WIPO, WORLD INTELL. PROP. ORG., http://www.wipo.int/ip-development/en/agenda/ [https://perma.cc/QA7Y-GDLV] (last visited Apr. 20, 2018).

6. The Indianapolis Business Journal reported that over the past 20 years, while the price of a gallon of milk climbed 23\% and the sticker on a Dodge Caravan minivan rose $21 \%$, the list price of the insulin Humalog, made by Eli Lilly and Co., shot up 1,157\%. Lilly's other insulin, Humulin, on the market since 1982, saw a price increase totaling nearly $800 \%$ over the last two decades. John Russel, Lilly Insulin Prices Come Under Microscope, IndianAPOLIS Bus. J. (Aug. 26, 2017), https://www.ibj.com/articles/65163-lilly-insulin-prices-come-under-microscope?utm_source=thisweek-in-ibj\&utm_medium=newsletter\&utm_campaign=2017-08-26 [https://perma.cc/K4F5-L8C5].

7. See infra Section III, for definition of the terms. 
exclusivity is, the international trade obligations relating to providing data exclusivity, and the impact of the data exclusivity obligations on access to medication issues with a specific focus on developing countries while keeping the U.S. regime as the vantage point to examine the issues. In doing so, this Article will address some of the more controversial issues that have arisen globally with reference to data exclusivity, within the larger access to medication debate. The Article's initial discussion on data exclusivity, in Section II, is followed by an outline in Section III of the historic origins of data exclusivity. Section IV provides a description of Article 39 of the TRIPS Agreement ${ }^{8}$ and its requirements. Section V addresses some of the recent questions from developing countries relating to the global prescriptions in the TRIPS Agreement and its translations into national policy specifically focusing on India as an example. The conclusion highlights the need to be cautious in establishing data exclusivity regimes.

\section{DAta EXClusivity: Definition \& DeBATE}

In order to appreciate why data exclusivity has become an important tool to promote or protect market exclusivity, it is important to understand what it is and how it operates. Thus, at the outset, this section outlines and defines data exclusivity. Then, it highlights the role of the data with reference to the pharmaceutical regulatory process. In doing so, this section displays how the data protection regime operates alongside patents. In all, this section provides the set-up for a discussion in the next section on how data exclusivity operates to sustain/create market monopoly, which, in turn, affects everyday access to medication for people.

In simple terms, data exclusivity operates to provide protection of data first submitted to a drug regulator to prove a chemical's therapeutic efficacy. The term "data exclusivity" refers to statutory provisions that protect clinical trial data in such a manner that it results in prohibition of reliance over the submitted data towards approval or submission of abbreviated applications for generic versions. That is, data exclusivity essentially treats the data of a drug generated in the course of clinical trials submitted to marketing approval agencies, typically, government regulatory agencies, as exclusive to the organization/corporation that

8. See Text of Annex 1C: Agreement on Trade-Related Aspects of Intellectual Property Rights, 33 I.L.M. 1197 (1994), reprinted in WorLd TRADE ORganizATION, THE RESUlTS OF THE URUGUAY Round of Multilateral Trade Negotiations 365 (1995) [hereinafter TRIPS Agreement]. 
conducted the clinical trial. ${ }^{9}$ In essence, for pharmaceuticals, data exclusivity protects the information relating to clinical trial results data. For example, if Drug A, whose patent is owned by innovator drug company AMBA Inc., is effective against say, psoriasis, but results in arthritis pain in patients, clinical trials over Drug A will show a pattern of cure and of side effects. The data from the clinical trial will be essential for national regulatory agencies, such as the Food and Drug Administration in the United States, to clear the drug for marketing after considering its safety.

It is common for most governments to regulate the marketing of pharmaceutical and agricultural products to ensure that they are safe and effective. Most governments seek assurances about the safety of the drug from the manufacturer. Developed nations tend to get more opportunities to test the evidence of safety and effectiveness as part of the marketing approval process, essentially because they are typically the markets where new drugs are first launched. Each country can seek a different type or amount of evidence of safety and efficacy. Some countries (e.g., the United States, European Community, and Japan) statutorily require the submission of an extensive amount of data to prove the safety of drugs, even if the product was approved by another government. ${ }^{10}$ Thus, globally, all regulatory agencies will require drugs to undergo data testing before it is approved. Before a drug can be approved for marketing, the drugs are required to undergo detailed clinical testing to ensure it is safe and efficacious. Such testing is more rigorous for New Chemical Entities (NCEs) to ensure its safety. ${ }^{11}$

Innovator pharmaceutical companies have been successful in asserting that the clinical trial data generated needs to be exclusive to the company that conducts the clinical trial. Pharmaceutical companies assert that such exclusivity of the data allows the drug company to recoup the investment on clinical trials, which can run up to four separate phases involving several patients, their confidential information, treatment

9. But see Erika Lietzan, The Myth of Data Exclusivity, 20 LeWIS \& CLARK L. REV. 91, 110, 118 (2016) (asserting that data exclusivity "is not a grant of anything to anyone" and that, from a regulatory perspective, "a subsequent entrant may file full applications for copies or near copies"). But, the article does not discuss the effect on consumers but creates a definitional distinction without fully exploring the practical real-life impact.

10. G. Lee Skillington \& Eric M. Solovy, The Protection of Test and Other Data Required by Article 39.3 of the TRIPS Agreement, 24 Nw. J. INT’L L. \& BUS. 1, 6 (2003).

11. A new chemical entity (NCE) is, according to the U.S. Food and Drug Administration, a drug that contains no active moiety that has been approved by the FDA in any other application submitted under section 505(b) of the Federal Food, Drug, and Cosmetic Act. 21 C.F.R. § 314.108(a) (2016). 
regimen, and information on side effects and safety regimes of the medication. ${ }^{12}$ It is a fact that the cost of undertaking the tests is considerable, involves human subjects, and can therefore be an arduous exercise. That said, the return for the risk of investing in creating new chemicals/compounds/drugs is a patent that gives a market monopoly for 20 years. ${ }^{13}$ Arguably, the test data highlighting the efficacy of a chemical need not be rewarded separately, especially if the monopoly for being the reward detrimentally affects access to medication for two reasons. First, the patent statute provides a 20-year exclusivity for new pharmaceutical innovations; ${ }^{14}$ second, independent Drug Information Journals repeatedly assert that the rate of "truly innovative" new medicines ranges as low as approximately $2-3 \% .^{15}$

In practice, a vast majority of so-called "new medicines," including those that are currently benefitting from patent protection, typically represent minor improvements over existing standards. ${ }^{16}$ Considering this, data protection works as a mechanism to add a layer of a different type of market protection. In effect, data exclusivity operates to provide a layer of protection in addition to patent protection for the data gathered by innovator drug companies. Needless to specify, just like patents, data

12. Kristina Lybecker, When Patents Aren't Enough: The Case for Data Exclusivity for Biologic Medicines, IP WATCHDOG (July 9, 2014), http://www.ipwatchdog.com/2014/07/09/patentsarent-enough-data-exclusivity-for-biologic-medicines/id=50318/ [https://perma.cc/Q7PN-43BX]. See also Trudo Lemmens \& Shannon Gibson, Decreasing The Data Deficit: Improving Postmarket Surveillance In Pharmaceutical Regulation, 59 MCGILL L. J. 943 (2014) (arguing that drug regulation would benefit from less industry control and highlighting how historically grown drug regulations have contributed to the development of industry control over clinical trials, which is one of the key factors behind the limits of pre-market evidence).

13. See generally 35 U.S.C. § 154 (1952).

14. Id.

15. See, e.g., Brian Godman et al., Are new Models Needed to Optimize the Utilization of new Medicines to Sustain Healthcare Systems?, 8 EXPERT REV. OF CliniCAl Pharmacology 77, 79 (2015) http://dx.doi.org/10.1586/17512433.2015.990380 [https://perma.cc/V94N-ELVP] ("Prescrire, a critical independent drug information journal, believed only $2 \%$ of new medicines or new indications for existing medicines in France were innovative and/or offered a real therapeutic advantage over existing treatments despite the hype.”).

16. See New drugs, new indications in 2015: little progress, and threats to access to quality healthcare for all, 36 REV. PRESCRIRE $136 \quad$ (2016) english.prescrire.org/en/3D3B93E1C3DE20A599FBA073C5442463/Download.aspx

[https://perma.cc/2M98-663R]; see also Prescrire Editorial Staff, New Products and new Indications in 2016: a System that Favours Imitation over the Pursuit of real Progress, 37 REV. PRESCRIRE 136 (2017) english.prescrire.org/en/955912A2E87C92B676874FA2C1354846/Download.aspx [https://perma.cc/84EN-FKNV] [hereinafter New Products, 2016] ("Little therapeutic progress was made in 2016, yet many medicines with no clinical value, uncertain efficacy or an unfavourable harmbenefit balance were authorized. This is due at least in part to the current system that drives pharmaceutical research and development. The primary focus is neither on patients' needs nor on delivering genuine therapeutic advances at affordable prices.”). 
exclusivity has come to represent an important tool for innovator companies to preserve market exclusivity to help keep the price of the pharmaceutical product high. Thus, in this Article, the term "market exclusivity" refers to the exclusive status that a drug enjoys because of data protection irrespective of whether the drug benefits from patent or any other form of protection. In other words, by protecting clinical trial data over a drug, the chemical components of which may even be in the public domain, the resulting exclusivity that the company enjoys in the market is termed as market exclusivity.

In the U.S., schemes such as orphan drug exclusivity and pediatric drug exclusivity are both examples of regulatory schemes that provide a new lease of "market” exclusivity by precluding submission or approval of any competing application even though the chemical in the drug may have been known and used for several years in the United States. In effect, this Article asserts that data exclusivity creates market exclusivity thus preventing competing applications that can benefit the consumers and lower the cost of the medication. ${ }^{17}$

\section{HISTORIC ORIGIN \& INTERNATIONAL OBLIGATIONS OF DATA EXCLUSIVITY}

The following section outlines two important aspects. First, it outlines the historic origins of the data exclusivity regime. Appreciating the historic origins of this regime is critical to appreciate the role of data protection to determine whether and how data protection can, from an economic, political, and trade perspective, serve national interests. Second, it elaborates on the international obligations outlined under Article 39 of the TRIPS Agreement to appreciate the breadth, limits, and built-in flexibilities of the international obligation that governs this regime.

Historically, data exclusivity evolved from unfair competition principles. Over a period, the concept of data exclusivity, while grounded on unfair competition principles, evolved into a more sui generis form of an intellectual property right. The underlying rationale or justification is based on the principle that it is unfair if data collected at the expense of one party becomes available for use by other parties to gain unfair commercial advantage.

17. Other writers have used the term "market exclusivity" to refer to prohibitions on submission or approval of any competing application, even if supported by a full complement of original data. See, e.g., Lietzan, supra note 9. 
Internationally, for the first time, unfair competition principles were captured as the basis for data exclusivity in Article 10bis of the Paris Convention for the Protection of Industrial Property. ${ }^{18}$ The basic outline of Article 10bis is that it requires member countries to provide for "effective protection against unfair competition." 19 The Paris Convention defined the term "unfair competition" as "any act of competition contrary to honest practices in industrial or commercial matters." ${ }^{20}$ As part of the protection against unfair competition, Article 10bis of the Paris Convention sought to: 1) establish "honest practices in industrial or commercial matters"; and 2) prevent actions such as dishonest manufacturing and other practices that mislead the public as to the nature and quality of the goods. ${ }^{21}$

The establishment of the $\mathrm{WTO}^{22}$ resulted in the inclusion of intellectual property laws within the larger umbrella of trade. Thus, the TRIPS Agreement, which established minimum standards of intellectual property provisions, also incorporated the provisions of the Paris Convention. ${ }^{23}$ The entire Part 7 of the TRIPS Agreement, which includes Article 39, elaborates three types of protections "[i]n the course of ensuring effective protection against unfair competition.” These are: 1) protection against unfair competition as detailed in the Paris Convention; 2) protection of "undisclosed information" as outlined in paragraph 2 of Article 39; and 3) protection for "data submitted to governments or governmental agencies" as outlined in paragraph 3 of Article 39. ${ }^{24}$ The following discussion captures each of the different types of protections envisaged under Article 39 of TRIPS.

\section{A. Protection Against Unfair Competition}

The Paris Convention, from where the TRIPS provisions were imported, outlines three aspects as forming a part of the obligations of members to establish protection against unfair competition. Subsection 3 of Article 10bis provides three specific examples of actions that represent unfair competition. ${ }^{25}$ They are: 1) action that creates confusion with

18. Paris Convention for the Protection of Industrial Property, Mar. 20, 1883, as last revised July 14, 1967, 21 U.S.T. 1583, 828 U.N.T.S. 305 at art. 10 [hereinafter Paris Convention].

19. Id.

20. Id.

21. Id.

22. See World Trade Organization, supra note 1.

23. TRIPS Agreement, supra note 8, Art. 39(2).

24. Id. at Art. 39(3).

25. Paris Convention, supra note 18. 
goods, or the industrial or commercial activities, of a competitor; 2) false allegations in the course of trade that result in discrediting the goods, or the industrial or commercial activities, of a competitor; ${ }^{26}$ and 3 ) misleading indications or allegations which misrepresent the nature, manufacturing process, characteristics, quality, or quantity of goods. ${ }^{27}$ The three examples specifically outline activities that lead to an unfair commercial advantage. This provision forms the basis for the TRIPS provisions dealing with undisclosed information. Importantly, none of the listed examples in the Paris Convention make any reference to undisclosed information. Hence, it is arguable that undisclosed information, which is the crux of the TRIPS provisions, does not fall within the larger umbrella of the first requirement of the Paris Convention, being unfair competition.

\section{B. Protection of "Undisclosed Information" as Outlined in Paragraph 2 of Article 39}

Article 39.2 of TRIPS relates to protection for undisclosed information, or, protection of trade secrets. In essence, it requires members to guarantee protection for any information that has commercial value which the owner lawfully controls and deems as a secret. ${ }^{28}$ This protection prevents unlawful disclosure by any means to ensure honesty in commercial transactions. Thus, any information, such as customer lists, internal manuals, parts information in factories, or such other information, can qualify for protection as long as the owner of the information believes that it has commercial value and maintains its secrecy. It is important to appreciate that TRIPS does not necessitate members to establish a trade secret statute (such as the state statutes in the United States which treat trade secrets as a form of property). It merely requires members to assure protection for undisclosed information. ${ }^{29}$

A protection regime for undisclosed information may be structured using the law of contract or other areas of law, which continues to remain the norm in some member countries. Thus, breach of contract, breach of confidence, and unlawful or fraudulent acquisition of undisclosed information by third-parties can also form a part of the cause of action under Article 39.2. Historically, countries have differed widely on the

\footnotetext{
26. Id.

27. Id.

28. TRIPS Agreement, supra note 8, at Art. 39(2).

29. Id.; see also Overview: the TRIPS Agreement, WORLD TRADE ORG., https://www.wto.org/english/tratop_e/trips_e/intel2_e.htm [https://perma.cc/KT9L-JCNM]; TRIPS Agreement, supra note 8.
} 
subject of protection of trade secret laws. Many of the differences have been owed to the question of whether the country treats trade secrets as a form of property. For instance, most European countries do not conceive of trade secrets as property. In fact, trade secrets are not considered as a form of an exclusive intellectual property right. Thus, they are not subject to the EU Enforcement Directive. ${ }^{30}$ Instead, the EU Enforcement Directive provides for certain procedures and remedies to ensure that there is a sufficient and consistent level of civil redress in the internal market in the event of unlawful acquisition, use, or disclosure of a trade secret. ${ }^{31}$ It merely facilitates the investigation and pursuit of intellectual property claims within the Union. In any case, Article 39.2 does not necessitate or mandate data exclusivity provisions. This view is supported by Shamnad Basheer in his exhaustive treatment of Article 39 of TRIPS where he outlines that a number of developing countries have adopted the view that TRIPS does not mandate undisclosed information to be treated as property and does not require granting of exclusive rights to the owner of the data. ${ }^{32}$

\title{
C. Protection for "Data Submitted to Governments or Governmental Agencies" as Outlined in Article 39.3
}

Article 39.3 of TRIPS states the following:

\begin{abstract}
Members, when requiring, as a condition of approving the marketing of pharmaceutical or of agricultural chemical products which utilize new chemical entities, the submission of undisclosed test or other data, the origination of which involves a considerable effort, shall protect such data against unfair commercial use. In addition, Members shall protect such data against disclosure, except where necessary to protect the public, or unless steps are taken to ensure that the data are protected against unfair commercial use. ${ }^{33}$
\end{abstract}

Thus, Article 39.3 requires members to provide protection against the unfair commercial use or disclosure of undisclosed test or other data that: 1) are submitted for the purposes of getting marketing approval for pharmaceutical or agricultural chemical products; and 2) involved the use

30. Directive (EU) 2016/943 of the European Parliament and of the Council of 8 June 2016 on the Protection of Undisclosed know-how and Business Information (Trade Secrets) Against their Unlawful Acquisition, use and Disclosure, OfFICIAL J. OF THE EUR. UnION (May 15, 2016), http://eurlex.europa.eu/legal-content/EN/TXT/?uri=CELEX:32016L0943 [https://perma.cc/YHJ2-AP7N].

31. Id.

32. Shamnad Basheer, Protection of Regulatory Data Under Article 39.3 of TRIPS: The Indian Context (2006).

33. TRIPS Agreement, supra note 8, at Art. 39(3). 
of new chemical entities, the origination of which involves considerable effort, except when the data is required to protect the public. ${ }^{34}$

Data exclusivity relates to the second requirement in Article 39 of the TRIPS Agreement (or the third form, depending on how it is viewed) and relates to protection for data submitted to regulators, governments, or governmental agencies to get market approval. The submitted data is usually critical to prove the safety of the application material/drug. The details of such protection are outlined in paragraph 3 of Article 39 of TRIPS and relate solely to "the submission of undisclosed test or other data" made as part of the approval process for marketing of pharmaceutical or agricultural chemical products which utilize new chemical entities. ${ }^{35}$ The protection is against unfair commercial use of "undisclosed test or other data" submitted to the FDA or the equivalent agencies provided it involves a considerable effort. ${ }^{36}$ The protection regime means to prevent the disclosure of the data and the unfair commercial use of the data. There is one exception though in Article 39.3, and that is where the data is deemed necessary to "protect the public." 37

For example, assume Company A has Drug XYZ for the cure of acne for which it plans to apply for patent protection. During this time, the company conducts clinical trials of over 300 patients and determines that the drug is safe to be used to treat acne. After the clinical trial is concluded, Company A submits the clinical trial information as part of the approval for marketing the drug. The data from the clinical trial may reveal information about the properties of the drug. For example, it can show that the drug is more effective on adolescents who have had a history of asthma, or that the drug can cause dangerous side effects on adolescents who have had a history of, say, childhood diabetes. At this time, Company A has two specific approval processes in place. First is to get a patent on $\mathrm{XYZ}$, and the next is to benefit from data protection for the clinical trial data collected about XYZ. These are two distinct, parallel processes and provide two layers of protection. First, Company A can get patent protection and benefit from the patent protection (which will allow the company to charge monopoly prices during the patent term) provided the drug clears the statutory requirements such as novelty and nonobviousness. Second, data exclusivity provisions result in protecting the data and preventing the use of the clinical trial information by a competitor during the data exclusivity term. The second layer of

$\begin{array}{ll}\text { 34. } & I d . \\ \text { 35. } & I d . \\ \text { 36. } & I d . \\ \text { 37. } & I d .\end{array}$


protection is independent of patent protection provided it involved considerable effort in collecting the data.

For innovator pharmaceuticals, protecting the clinical trial data provides an economic opportunity by creating a new market (thus, the definition of market exclusivity) on the information relating to safety of the drug. Thus, it helps provide market exclusivity for a compound that may even fail the scrutiny for protection under the patent statute. ${ }^{38}$ Critics point out correctly that pharmaceutical companies do prefer to make general trial information available at the earliest opportunity with a view to boost share prices. For example, with Drug XYZ, it would be common for Company A to highlight general trial information of the drug, such as that it can cure acne with very little side effects, without discussing severe side effects on segments of population, such as minors on asthma medication or children with diabetes. ${ }^{39}$ The general clinical trial information about drugs are increasing and proactively tracked among health authorities as well as venture capitalists for various market related reasons, such as determining potential funding models. ${ }^{40}$ Release of limited but early trial information can allow pharmaceutical companies to seek more funding for the launch of their new medicines. But, such general disclosures of pharmaceutical companies aimed at securing funding need to be carefully distinguished from data that bear critical patient information, including side effects and success details, which will remain protected under data protection laws.

\section{COURSES OF ACTION FOR DEVELOPING COUNTRIES}

The above discussion highlighted the historical origins, the prevailing form of data exclusivity, and some of the international as well as trade law questions involved with it, including the built-in flexibilities in Article 39 of TRIPS. The discussion below ventures into the question

38. See definition of market exclusivity, supra Section II.

39. But see New Products, 2016, supra note 16, at note 2 (asserting how new products in the year 2016 represented no or limited therapeutic advancement; further discussing how pharmaceuticals are approved applications without demanding adequate supporting data of clinical trials).

40. There is an increasing level of pro-activity among health authorities in Europe to track new medicines early and feed this information into their potential funding models. See, e.g., Irene Eriksson et al., The Early Awareness and Alert System in Sweden: History and Current Status, 8 FronTIERS IN Pharmacology 674 (Oct. 5, 2017), https://doi.org/10.3389/fphar.2017.00674 [https://perma.cc/RCX4-7FKK]; see also Rickard Malmstrom et al., Dabigatran - A Case History Demonstrating the Need for Comprehensive Approaches to Optimize the Use of New Drugs, 4 FRONTIERS IN PHARMACOLOGY 39 (May 14, 2013), https://www.ncbi.nlm.nih.gov/ pmc/articles/PMC3653065/ [https://perma.cc/X4HF-UDWP] (discussing example of activities between European countries to share data). 
of the options developing countries have and how these options could affect these nations. In doing so, this section attempts to provide guidelines especially for developing countries that are considering adopting a regime of data exclusivity styled along the lines of what prevails in the United States. The section below outlines questions that arise from the built-in flexibilities of Article 39.3 and questions that arise when effectuating a data exclusivity regime in other countries.

The most important element of Article 39 is the breadth. The rhetoric from innovative pharmaceutical companies, notwithstanding the broad prescription in Article 39.3, is meant to give WTO members the freedom to set their own rules in a flexible manner with a view to specifically facilitate members to interpret the Article's principal terminology. ${ }^{41}$ Each element of the Article has built-in flexibilities that may be critical to achieve national objectives for developing countries.

\section{A. Defining “Undisclosed” Test Data}

Under Article 39.3, WTO Members have an obligation to protect undisclosed data against unfair commercial use. Typically, undisclosed data relates to clinical trial information disclosed to regulators but deemed undisclosed to third parties. The underlying rationale behind treating data disclosed to regulators as "undisclosed" is that innovator pharmaceutical companies invest money into generating safety details and data for new and innovative drugs or combinations. ${ }^{42}$ That is, Company A invests money by conducting clinical trials on the drug to determine its efficacy. If that data is allowed to be used by a second applicant for getting marketing approval for the same drug, in effect that regulatory practice gives an unfair commercial advantage to the second applicant in that the second applicant does not have to generate the data which was required of the first applicant and hence results in significant economic saving. ${ }^{43}$ While this reasoning is cited to explain the rationale behind data

41. Wael Armouti \& Mohammad F.A. Nsour, Data Exclusivity for Pharmaceuticals: Was It the Best Choice for Jordan Under the U.S.- Jordan Free Trade Agreement?, 17 OREGON REV. OF INT. L. 258, $260 \quad$ (2016), https://law.uoregon.edu/images/uploads/entries/Nsour.pdf [https://perma.cc/VDM5-466R].

42. Jacques Gorlin, Encouragement of New Clinical Drug Development: The Role of Data Exclusivity, INT'L FED'N OF PHARMACEUTICAL MANUFACTURERS Ass'N (IFPMA) (2000), http://www.who.int/intellectualproperty/topics/ip/en/DataExclusivity_2000.pdf [https://perma.cc/NN7E-UAMS].

43. Id. at 15; Protection of Undisclosed Information and Control of Anti-Competitive Practices, APEC TRIPS Seminar: 17-19 May 1995, Presentation by New Zealand, http://www.who.int/intellectualproperty/topics/ip/en/DataExclusivity_2000.pdf [https://perma.cc/B7R3-P8YJ]. 
exclusivity, it is important to note that a competing generic applicant tends to price the drug much lower, thus, benefitting the consumer. Moreover, as mentioned earlier, conducting clinical trials is a part of the risk that innovator companies undertake in order to gain the enormous market benefits that come with patent protection. Generally, the first applicant typically seeks patent protection which, if successful, leads to monopoly profits during the statutory period of exclusivity meant to recoup "research and development." ${ }^{44}$ While Article 39 necessitates protection of undisclosed data, the breadth of the language and lack of definition of the terms is in consideration of the fact that not all countries were convinced that patent protection would not adequately help recoup the cost of clinical trials. ${ }^{45}$

\section{B. "Undisclosed" to Whom?}

Article 39 necessitates protection of data disclosed to regulators and thus raises the question of whether the obligation to not disclose the data applies only against third parties or does it include the regulators/government officials of the members. The negotiating history of Article 39.3 of TRIPS suggests "non-reliance on the originator's data for a particular period of time" as the definition of the obligation to protect the data against “unfair commercial use.”46 Typically, governments do

44. The role of patent protection to minor innovation and how it detrimentally affects the cost of medication has become a matter of debate. Researchers and international organizations have highlighted the importance of access to medication issues. See, e.g., Experts in Chronic Myeloid Leukemia, The Price of Drugs for Chronic Myeloid Leukemia (CML) is a Reflection of the Unsustainable Prices of Cancer Drugs: From the Perspective of a Large Group of CML Experts, 121 BLOOD J. 4439 (2013), http://www.bloodjournal.org/content/121/22/4439?sso-checked=true [https://perma.cc/KG5B-PVTD]; see also Report of the United Nations, supra note 5; see generally WHO study, PHARMALOT (May 31, 2016), https://www.statnews.com/pharmalot/2016/05/31/gileadhepatitis-drug-prices-who/ [https://perma.cc/SX83-MJDE]. See also Over 1 Million Treated with Highly Effective Hepatitis C Medicines, supra note 5; Narcyz Ghinea et al., If We Don't Talk about Value, Cancer Drugs will Become Terminal for Health Systems, THE CONVERSATION (July 26, 2015), http://theconversation.com/if-we-dont-talk-about-value-cancer-drugs-will-become-terminal-forhealthsystems-44072 [https://perma.cc/KWY6-EWP3] (discussing a group of oncologists urging patients to talk about the price of medications).

45. Jayashree Watal, Intellectual Property Rights In The WTO AND DeVeloping CountRIES, 199 (Kluwer Law International) (2001); see also Skillington \& Solovy, supra note 10, at 15 (discussing how U.S., Swiss, and European proposals were used for the Uruguay Round Negotiations and also discussing why developing countries should give lesser protection for test data).

46. Skillington \& Solovy, supra note 10, at 20 (citing Jaques J. Gorlin, AN ANALYSIS OF THE Pharmaceutical-Related Provisions of the TRIPS (InTEllectual Property) Agreement 48 (1999)) ("United states negotiators agreed to drop the non-reliance language, because they viewed the phrase as no more than 'belts and suspenders'; that is, the accepted definition at the time of 'production against unfair commercial use' included non-reliance for a fixed period of time for new chemical entities and the second phrase was, therefore, not need.”). 
not rely on the data as much as use it to examine or analyze the data towards approval. Under Article 39, governments have a clear duty to ensure non-reliance of undisclosed data by third parties on the originator's data. An early draft of the agreement dated November 23, 1990 may be informative on the question of whether governments are also required to not rely on the data. The 1990 draft outlined that "the data may not be relied upon for the approval of competing products for a reasonable time, generally no less than five years ...." ${ }^{4}$ A plain reading of this draft suggests that governments could not rely on the data for approving competing products. This draft was meant to be included as a recommendation and not an obligation under Article 39.3. However, this draft was not adopted. Instead, the currently prevailing broad language was inserted into Article 39 leaving room for the possibility that, under the final agreement, the language regarding extending the non-disclosure obligation remain flexible for countries to take a variant approach.

\section{What Amounts to "Unfair Commercial Use?"}

Article 39 requires that undisclosed information not be used in a manner resulting in an unfair commercial advantage. The definition of "unfair commercial use" remains closely tied to the definition of undisclosed information, discussed above. In fact, the terms of Article 39.3 are couched using the definition of the term "unfair commercial use" as the basis. ${ }^{48}$ Perhaps, the most outstanding and controversial question revolving around this phrase is whether the use of the data by a government authority would amount to "unfair commercial use," or would it be legitimate use by the state?

The terms "unfair" and what amounts to "commercial use" are undefined in the TRIPS Agreement, thus providing the flexibility for members to define the elements constituting unfair commercial use. It would be advantageous to define these terms using a national scale, while carefully considering national health requirements. Developing countries may and should choose to define the terms strictly to include uses of the data by a commercial/corporate entity but in a manner leaving out the use of the data by government authorities. Arguably, the use of the data by government authorities for public or administrative purposes can and will indirectly qualify as commercial because it would facilitate use by a thirdparty applicant. On a plain reading, TRIPS does not elaborate on

47. Id. at 32

48. Id. 
"indirect" commercial use. In any case, such indirect use may still be justified under the Article's broad "public use" exception. ${ }^{49}$

Alternately, the intermediate position that also conforms to TRIPS is for national governments to consider instituting specific public interestbased exceptional circumstances — such as when a compulsory license has been issued conforming with the TRIPS requirements - to permit such indirect commercial use of the data by regulators. Chile's Industrial Property Law serves as a great example of this. When, on account of a bilateral free trade agreement with the United States, Chile reluctantly introduced data exclusivity provisions, it carved out several public interest-based exceptions to the exclusive rights over the data (as well as over the patent monopoly) such as including "reasons of public health, national security, public noncommercial use, national emergency, or other circumstances of extreme urgency; or, the pharmaceutical product is the subject of a compulsory license."50

Overall, countries such as India would benefit from following the developing country position submitted in 2001 to the TRIPS Council asserting that a drug regulatory authority's use of originator test data as a basis for granting approval to a generic product did not constitute an "unfair commercial use." ${ }^{51}$ Having taken that position in the international forum, developing countries should not hesitate to institute it in national legislation. Thus, what amounts to unfair use in a commercial manner needs elaboration using national health care requirements. The requirement in Article 39 is grounded on the assumption that without data exclusivity, the originators of the innovative drug would be placed at an unfair commercial disadvantage when compared to their generic competitors; especially when considering their investments in conducting the clinical trials to meet the mandated requirements set by regulatory bodies for drug approval. But, generic manufacturers sell at a fraction of the cost, in turn, benefitting the consumers. For countries that prioritize access to medication and national health care, it is worth prioritizing consumer interests. Countries such as India, where healthcare tends to be an individual expense, should carefully take these parameters into due consideration.

49. Id. at 34-35.

50. Industrial Property Law, 19.039 (2006) (Chile); see also CARSTEN FINK, INTELLECTUAL Property Rights, Preferential Trade Agreement Policies for DeVelopment: A Handbook 394 (Jean-Pierre Chauffour \& Jean-Christophe eds., 2011).

51. Developing Country Group's Paper, TRIPS: Council Discussion on Access to Medicines, WORLD TRADE ORG. (June 19, 2001), https://www.wto.org/english/tratop_e/trips_e/ paper_develop_w296_e.htm [https://perma.cc/REF9-LDEP]. 
The built-in flexibility in Article 39 should effectively be used by all countries, especially those that are in the developing spectrum, to mandatorily outline that the use by government authorities to assess the efficacy and toxicity of a pharmaceutical product does not amount to "unfair commercial use." Thus, the prevalence of "unfair commercial use" should automatically be deemed if or when a competitor directly accessed the originator's submitted test data during the protection period. As such, such a reading would be in line with the requirement in Article 39.3 and will result in governments protecting the innovator's data from unfair access by third parties.

Not all scholars agree with this line of interpretation. For instance, a view in opposition expounded by Shamnad Basheer terms the above as a "permissive reliance model." ${ }^{52} \mathrm{Mr}$. Basheer disagrees with this model and asserts that a closer look at the wording of Article 39.3 suggests that the obligation to "[p]revent unfair commercial use of regulatory data is primarily addressed to regulatory agencies/government, as opposed to a private third party likely to have access to regulatory data in an unauthorized manner." 53 He asserts that any reading of the term "unfair" in a manner allowing regulatory authorities to rely on originator's data to approve a competing generic product is flawed. ${ }^{54}$ He seems to favor the "compensatory liability model," which suggests that governments can rely on the data only when compensation is provided. ${ }^{55}$ The compensatory liability model, in suggesting that regulators need to compensate for relying on the originator's data, treats the data as property. Even Mr. Basheer himself agrees that Article 39 of TRIPS does not mandate the treatment of the data as property. ${ }^{56}$ In any case, even within taking the compensatory liability model proposed by Mr. Basheer, governments should still be able to carve out a "public interest-based" reliance exception. One example would be where protected data is used towards the approval of a generic drug when a compulsory license has been issued in compliance with the TRIPS prescription. Such allowance will be in consumer interest and can facilitate the immediate marketing of the drug either as soon as the patent or the data exclusivity period expires, as the case is.

\footnotetext{
52. Basheer, supra note 32, at 19.

53. Id. at 20.

54. Id. at 23 .

55. Id.

56. Id. at 16 .
} 


\section{What is a New Chemical Entity?}

Just like the other terms, the term "new chemical entity" has not been defined under Article 39. The lack of definition provides adequate breadth and flexibility for members to define the term based on national interest. Drug regulatory agencies, such as the USFDA, define a "new chemical entity" as a drug "that contains no active moiety that has been approved by FDA in any other application submitted under section 505(b) of the Act." ${ }^{27}$ This is a classic example of how each country can define the term based on the type of industry it wants to protect. There is nothing in the Article that requires the definition of a new chemical entity to relate to the time when the active ingredient was first discovered or synthesized. ${ }^{58}$

The following example underscores the need to define NCEs carefully. Assume Company A files for patent protection and also seeks approval for marketing of Drug MNO. Now, assume that Competitor B opposes the patent application successfully such that the patent application is denied. The information in the patent application will fall into the public domain and can be rightfully used by generic drug companies. The question is whether the application material, being MNO, will continue to be considered a "new" chemical entity for the purposes of the marketing of MNO. That is, whether the denial of patent protection should result in the chemical entity losing its status of "new chemical entity” for regulatory purposes.

A definition that follows the United States for defining a new chemical entity will result in providing data exclusivity for a period of five to seven years even when the patent application has failed. Thus, Company A will benefit from an indirect market monopoly (which, in this Article, is termed as market exclusivity) over the Drug MNO for the period when the clinical trial data is considered exclusive even though its patent has been denied. That is, when the patent is denied leaving MNO susceptible for use by a generic drug company, it will still prevent such companies to get marketing approval for MNO. This is because the test data (the data on the drug's success for use against acne, its side effects information, etc.) are protected under the data exclusivity regime of the United States. Therefore, a generic drug company will be unable to use the innovator's clinical data as part of its application to seek marketing

57. See Small Business Assistance: FAQ for New Drug Product Exclusivity, FDA (Feb. 11, 2016), www.fda.gov/drugs/developmentapprovalprocess/smallbusinessassistance/ucm069962.htm [https://perma.cc/C96Y-8SK5].

58. See Federal Food, Drug, and Cosmetic Act, 505(b), 21 U.S.C. § 355 (1938); but see Gorlin, supra note 42. 
approval before the end of the data exclusivity period, which is a good seven years during which time consumers will be unfairly denied access to medication otherwise in the public domain. For consumers, Company A's market exclusivity comes at a financial cost as well as at the cost of access to the medication. Of course, generic drug companies are free to conduct their own clinical trials considering that the drug is not a subject of patent protection. ${ }^{59}$ But, such duplication of clinical trials will result in subjecting a new set of patients to the same clinical trial and involves additional: 1) cost to conduct the trial; and 2) delay in manufacturing the generic drug while the trial is being conducted. Thus, generic drug companies duplicating a clinical trial already conducted elsewhere will result in duplicative burdens in terms of time and cost. While the cost of the trial will be added to the cost of the drug and passed onto consumers by unnecessarily raising the cost of generic drugs, the delay from duplicating the clinical trial will result in delaying access to the consumers.

Importantly, Article 39 necessitates protection of "new" chemical entities. But, it should be up to the member country to define the constituents of "new" chemical entities. The language in Article 39 provides adequate flexibility to construe the term differently. Thus, there is nothing to prevent a member from treating a chemical whose patent has been invalidated or denied as not being "new." After all, innovator pharmaceuticals have asserted that patent status should be linked to providing regulatory clearance (patent linkage).$^{60}$ Along the same lines, countries that house generic drug companies should connect patent status with the definition of "new" for the purposes of defining NCEs. Needless to highlight, originator pharmaceutical companies prefer an interpretation that treats the term "new chemical entities" as a regulatory concept separate from the "novelty" requirement of patent protection, although there is no basis for such a treatment. ${ }^{61}$

59. But see Lietzan, supra note 9 , at 95 (asserting that data exclusivity does not truly fall within “exclusivity” because it creates a different path for a second applicant).

60. See, e.g., Pharmaceutical Research and Manufacturers of America (PhRMA) Special 301 (2014), http://phrma-docs.phrma.org/sites/default/files/pdf/2014-special-301-submission.pdf [https://perma.cc/6EPS-SZGC] (asserting the need for linkage to impose unilateral pressure on countries even though it is not a trade obligation); see also Brook K. Baker, Ending Drug Registration Apartheid: Taming Data Exclusivity and Patent/Registration Linkage, 34 AM. J.L. \& MED. 303, 343 (2008); see also Ron Bouchard et al., Empirical Analysis of Drug Approval-Drug Patenting Linkage for High Value Pharmaceuticals, 8 Nw. J. OF TECH. AND INTELL. PROP. 174, 174-227 (2010), https://scholarlycommons.law.northwestern.edu/cgi/viewcontent.cgi?article=1102\&context=njtip [https://perma.cc/RC5S-RHEQ].

61. See Gorlin, supra note 42. 
Developing countries, particularly those that house generic drug companies, such as India, should define the boundaries of the term "new" carefully considering the patent status as well as the protection status for the data abroad. Some countries have defined the term to encourage innovator pharmaceutical companies to register new chemical entities as soon as they apply for marketing elsewhere in the world. ${ }^{62}$ Such a definition means to prevent evergreening of the data and facilitate quicker entry of the generic product into the market. For example, under a regulation circulated under Jordan's Food and Drug Administration (JFDA) law, "in order to be considered new, a chemical entity should be submitted for registration to the JFDA within eighteen months of its first approval in any other country." ${ }^{3}$ A definition along these lines can prevent misuse by the originator during the data protection period.

I believe that developing countries, especially those like India and Brazil, should appreciate that for pharmaceutical companies and countries that are lobbied by them, such as the United States, data exclusivity represents an economic opportunity to preserve their market for just a little longer even if the patent is invalidated. Unlike these countries, for developing countries where the access to medication question remains dominant, it is important to use all available flexibilities and establish a coherent approach.

\section{E. “Known” Chemical Entities}

The definition of the term "new chemical entity" in Article 39 raises several questions on the definition of "new." 64 It particularly raises questions with reference to "known" chemical entities. Whether "new" chemical entities also include chemicals or formulations already "known" within the same or another related field remains unresolved. The term "known" chemical entities typically tend to refer to different forms of an existing chemical entity, such as esters, ethers, polymorphs etc., and newer combinations or formulations of known chemicals that yield benefits that may be different from already known benefits. ${ }^{65}$ Generally, if the chemical entity had been previously received and subject to scrutiny by the drug regulatory authority, it should not benefit from a second

62. See generally Armouti \& Nsour, supra note 41.

63. See id.; see also JORDAN FOOD AND DRUG ADMINISTRATION, http://www.jfda.jo/Default.aspx [https://perma.cc/Q3U5-AXSH] (last visited Aug. 15, 2014).

64. Basheer, supra note 32 (discussing the various interpretations of the "new" definition, such as whether "new" refers to the first global application in the world; and whether the term includes chemical entities previously known or disclosed).

65. See generally, infra note 67. 
protection period even if the application is for a different disease or treatment. Such a definition of "known" can also conserve regulatory time spent in examining different versions of known chemical entities and can help channelize that time to more thoroughly examine new drugs and chemical entities, especially in places where regulatory resources may be lesser, such as in developing countries.

On this question, Canada serves as a great example for developing countries. It does not allow data protection for known drugs (especially if they were previously used to develop orphan indications) on the grounds that such drugs would not be deemed to be "innovative." ${ }^{66}$ In fact, under the Canadian Food and Drug Regulations of 2006, an "innovative drug" is defined as "a drug that contains a medicinal ingredient not previously approved in a drug by the Minister [of Health] and that is not a variation of a previously approved medicinal ingredient such as a salt, ester, enantiomer, solvate or polymorph." ${ }^{67}$ Further, several decisions of the Federal Court of Canada have upheld a strict interpretation of the terms "previously approved" and "variation" within the definition of "innovative drug." For example, in a decision involving Epicept Corporation's application to market the drug CEPLENE for a new oncology indicator, the court determined that the active ingredient (histamine dihydrochloride) was not "innovative" and thus could not benefit from data protection because it had been previously approved for an unrelated homeopathic use. ${ }^{68}$ Importantly, the approval for CEPLENE, based on a full package of clinical trial data, was refused even though homeopathic drugs are not approved in the same manner as therapeutics in Canada. ${ }^{69}$ Similarly, the Federal Court of Appeals of Canada sustained a decision that refused to treat THALOMID as an "innovative drug" on the basis that its active ingredient (thalidomide) had been previously approved in Canada decades earlier. ${ }^{70}$ This is despite the fact that the earlier drug had another clinical usage and was subsequently withdrawn from the market for being unsafe. ${ }^{71}$ The applicant, Celgene, claimed its drug was in fact an "innovative” drug in view of newly generated clinical

66. Megan Kendall \& Declan Hamill, A Decade of Data Protection for Innovative Drugs in Canada: Issues, Limitations, and Time for a Reassessment, 35 BioteChNOL L. REP. 259, 259-67 (2016), https://www.ncbi.nlm.nih.gov/pmc/articles/PMC5178005/ [https://perma.cc/D3TP-SBXE].

67. See Canadian Food and Drug Regulations, C.R.C., c. 870/2017, C.08.004.1(1).

68. Epicept Corp. v. Canada (Health), [2010] F.C. 956 (Can. Ont.).

69. Id.

70. Celgene Inc. v. Canada (Health), [2012] F.C. 154 (Can. Ont.).

71. Canada (Health) v. Celgene Inc., [2013] F.C.A. 43 (Can. Ont.). 
trial data for a completely different disease condition than the original product. $^{72}$

The United States treats "new" to include "new dosage forms and combinations" (which essentially includes known uses of known entities). In the United States, the prior approval of a drug containing an active ingredient does not preclude a finding of the presence of active ingredients in a later application. ${ }^{73}$ In trade negotiations, especially in the Free Trade Agreements with other countries, the United States tends to prefer a definition that does not clearly differentiate known chemical entities from new chemical entities that are eligible for data protection. Developing countries should understand the various options and what each of these options entails to their national interests before blindly succumbing to pressure from the United States.

\section{F. Does New Chemical Entity Include Biologics?}

On the face of it, biologics are not included within the scope of Article 39.3's requirement to protect new chemical entities. ${ }^{74}$ The NCEs should not, by definition, include biologics. The decisions of the Supreme Court of the United States, holding that naturally occurring products are not per se patentable when denying the patentability of an isolated, naturally occurring DNA sequence, makes it harder to justify the protection of any test data by treating biologics as "new." 75 Similarly, the USPTO Guidance for Determining Subject Matter Eligibility of Claims Reciting or Involving Laws of Nature, Natural Phenomena, \& Natural Products asserts that:

[C]hemicals derived from natural sources (e.g., antibiotics, fats, oils, petroleum derivatives, resins, toxins, etc.); foods (e.g., fruits, grains, meats and vegetables); metals and metallic compounds that exist in nature; minerals; natural materials (e.g., rocks, sands, soils); nucleic acids; organisms (e.g., bacteria, plants and multicellular animals); proteins and peptides; and other substances found in or derived from nature ... [ [will be considered natural and hence, will be not be considered patentable unless the] claim as a whole recite[s] something significantly different

72. Kendall \& Hamill, supra note 66.

73. Aparna Nemlekar, Nicole Stakleff \& Raymond Miller, FDA Is Evolving on Qualifications For 'New Chemical Entity', PEPPER HAMILTON LLP (Sept. 7, 2016), http://www.pepperlaw.com/publications/fda-is-evolving-on-qualifications-for-new-chemical-entity2016-09-07/ [https://perma.cc/RZ3Y-YQMP].

74. TRIPS Agreement, supra note 8.

75. Ass'n for Molecular Pathology v. Myriad Genetics, 569 U.S. 576 (2013). 
than the judicial exception(s). ${ }^{76}$

Similar language is employed in the 2016 Guidelines clearly highlighting requirements for rejection on the basis of the law of nature or natural phenomenon exception. ${ }^{77}$

Considering that data exclusivity is for "new" "chemical" entities, it would be harder to justify data protection for biologics that are denied patent protection because they lack novelty on account of falling within the scope of "naturally occurring products." There is nothing in Article 39 that requires something that is not considered "new" in patent law to be treated as "new" for the purpose of data exclusivity.

Nevertheless, there is also a line of argument that asserts that because patents are likely to be either not granted or invalidated more quickly with biologics, drug companies would be discouraged from investing in research over biological substances which remain important for certain types of therapies, such as cancer therapies. ${ }^{78}$ Others assert that "biotech products, like monoclonal antibodies, are very difficult for generic companies to develop and the absence of data exclusivity in a country would discourage the originator company from entering this market, which would have the deleterious effect of depriving people of the benefits of these drugs." 79 These arguments are typically used to lobby higher levels of data protection on the grounds that innovative firms need such protection for their investment in clinical trials and data collection, regardless of patentability of the involved biologics. ${ }^{80}$ It is notable that in the United States the Affordable Health Care for America Act in 2009 extended a 12-year exclusivity period for biologics. ${ }^{81}$

These arguments are not persuasive for developing countries considering that their obligations are limited to those outlined in Article 39 of TRIPS. Further, the current abysmal state of the health care system in the United States, the high cost of prescription drugs, and the criticisms by public health and consumer groups opposing the enormous influence

76. Andrew Hirshfeld, USPTO Procedure For Subject Matter Eligibility Analysis Of Claims Reciting Or Involving Laws of Nature, Natural Phenomena, \& Natural Products (Mar. 4, 2014).

77. See Robert Bahr, Formulating a Subject Matter Eligibility Rejection and Evaluating the Applicant's Response to a Subject Matter Eligibility Rejection (Mar. 4, 2016), https://www.uspto.gov/sites/default/files/documents/ieg-may-2016-memo.pdf [https://perma.cc/ZX42-SF2W].

78. Skillington \& Solovy, supra note 10, at 2-6.

79. See Armouti \& Nsour, supra note 41.

80. See Lybecker, When Patents Aren't Enough, supra note 12.

81. Affordable Health Care for America Act, 155 Cong. REC. H12623, 12784 (Nov. 7, 2009). 
that pharmaceutical companies have over the various American administrations are all reasons for not following the U.S. system. ${ }^{82}$

\section{G. Reliability of Clinical Trial Information from Other Countries}

The question of whether it is acceptable to rely on clinical trial data of another country has much significance to countries that do not house innovative pharmaceutical companies. Historically, before the TRIPS Agreement was negotiated, most countries allowed reliance on originator test data to approve generic products. Generic manufacturers had to only prove bioequivalence, which is that their product is chemically identical to the brand name, original product. ${ }^{83}$ The approach that has been historically followed - the pre-TRIPS approach—was consumer friendly in that it enabled introduction of generics into the market as soon as the patent expired. The importance of preserving the historic approach is underscored by the recent United Nations Secretary-General's HighLevel Panel on Access to Medicines Report, ${ }^{84}$ the WIPO Development Agenda, ${ }^{85}$ and the WHO Studies, ${ }^{86}$ all of which highlight the importance of access to medication. It is a documented fact that generics have not only been able to save costs, but have also enabled access to medication in several parts of the world. ${ }^{87}$

82. See Test Data Protection for Medical Inventions, KNOWLEDGE ECOLOGY InT’L (Aug. 8, 2017), https://www.keionline.org/testdata [https://perma.cc/QEG4-G2TL].

83. Generic manufacturers should establish bioequivalence for each compound. Note that bioequivalence can be proved for a different salt too, although, within agreed bioequivalence levels. See generally Christoph Baumgärtel et al., What Lessons can be Learned from the Launch of Generic Clopidogrel?, 1 GABI J. 58 (Mar. 5, 2012), http://gabi-journal.net/what-lessons-can-be-learnt-fromthe-launch-of-generic-clopidogrel.html [https://perma.cc/C4HU-Q9BE] (highlighting issues that arise with reference to generic clopidogrel because manufacturers used the technicalities of Plavix's European patent protection early and produced clopidogrel in a different salt, such as the besylate salt. Thus, the generic version was launched for secondary prevention of certain uses clearly and strategically excluding primary syndromes. This prevented health authorities from using the generic medication for some conditions thus sustaining the use of the branded medication.). Especially when there are secondary patents, there have been controversies about how some pharmaceutical companies misuse this provision. For example, with the drug pregabalin, the manufacturer had different patents for different indications. The company threatened to take physicians to court if the generic version was prescribed to treat neuropathic pain instead of the patented version. See Brian Godman et al., Generic Pregabalin: Current Situation and Implications for Health Authorities, Generic and Biosimilar Manufacturers in the Future, 3 GABI J. 125 (June 12, 2015), https://strathprints.strath.ac.uk/53359/ [https://perma.cc/ZRH3-TN3V].

84. See Report of the United Nations, supra note 5.

85. See generally Development Agenda for WIPO, supra note 5.

86. Silverman, supra note 5; see also Over 1 Million Treated with Highly Effective Hepatitis C Medicines, supra note 5.

87. See, e.g., Generics Could cut Costs of Cancer Drugs by Over 99\%, GABI (Apr. 14, 2017), http://www.gabionline.net/Generics/Research/Generics-could-cut-costs-of-cancer-drugs-by-over-99 
Currently, India, like the United States, has established regulations that require an applicant for a new drug to engage in extensive testing and clinical trials. But, the requirement may be waived for purposes of "public interest" or if the new drug has been approved and marketed for several years in other countries. ${ }^{88}$ Thus, the Indian Drugs and Cosmetics Act of 1940 provides for data exclusivity for a "new drug" under section $122 \mathrm{E}$ (for a total period of four years from the date of approval). ${ }^{89}$ The Indian law does not connect the definition of a "new drug" with its patent status but defines it as a drug which has not been used in the country to any significant extent. A new drug in India is a product that: 1) has not been recognized or licensed in India; 2) has been recently licensed and approved for marketing; 3 ) is a combination drug individually approved earlier but will be marketed as a combination; or 4) is a vaccine and Recombinant DNA (r-DNA) derived drug.

Similarly, the Argentinian Law on the Confidentiality of Information and Products, No. 24,766 outlines that with respect to new chemicals not previously registered in Argentina or in any other country (listed in Addendum I), information on the effectiveness and safety of the product should be provided to the local Public Health Authority. ${ }^{90}$ The law further adds that the product already registered in Argentina or in any of the countries listed in the Addendum, will be authorized by the Public Health Authority for marketing. ${ }^{91}$ Thus, known chemicals (even those unknown nationally but known in addendum countries) are covered under this.

[https://perma.cc/A35S-B9RH]; Brian Godman et al., Payers Endorse Generics to Enhance Prescribing Efficiency: Impact and Future Implications, a Case History Approach, 1 GABI J. 69, 6983 (2012), http://gabi-journal.net/payers-endorse-generics-to-enhance-prescribing-efficiencyimpact-and-future-implications-a-case-history-approach.html [https://perma.cc/3SEA-TN44] (asserting that the savings from generics when compared with the originator is considerable); see also Alexandra Cameron et al., Switching from Originator Brand Medicines to Generic Equivalents in Selected Developing Countries: How Much Could be Saved?, 15 ElSEVIER, VALUE IN HEALTH 664 (2012), http://www.valueinhealthjournal.com/article/S1098-3015(12)01547-1/pdf [https://perma.cc/A86N-3JSX]; see also Brian Godman et al., Multiple Policies to Enhance Prescribing Efficiency for Established Medicines in Europe with a Particular Focus on Demand-Side Measures: Findings and Future Implications, 5 Frontiers IN Pharmacology 1 (June 2014) (highlighting some of the policies that Europe pursued to maintain universal health care).

88. See Drugs and Cosmetics Act, 1940, at § 122E (amended 1995) (India), http://cdsco.nic.in [https://perma.cc/7Z2T-28DE].

89. Id.

90. See Law of Confidentiality on Information and Products that are Legitimately Under the Control of a Person and is Disclosed in a manner Contrary to Honest Commercial Uses, No. 24,766 Articles 4 and 5 (Arg.); Data Exclusivity: Encouraging Development of New Medicines, INT'L FED'N of Pharmaceutical Manufacturers Ass'N, (July 2011) at 10-11, https://www.ifpma.org/resource-centre/data-exclusivity-encouraging-development-of-newmedicines/ [https://perma.cc/UJ4D-CLRG].

91. Id. 
The Indian and Argentinian requirement discussed above is a standard norm to avoid duplication of trials in different jurisdictions which can result in increasing the cost and delaying the introduction of a generic drug in the market. Clinical trials are costly not just financially but also in terms of the patient suffering. That is, during the time period when a trial is being conducted, other patients wait in the pipeline; similarly, the administering of the drug as part of the trial to wrong patient groups can lead to detrimental side effects. So, if a study has already been extensively conducted, unless there are red-flags in that study that require further investigation, or population variations that warrant a different study (for example, impact of a drug on Asians versus African Americans), to reinvent the same study may just be an exercise draining valuable time and cost.

The use of data from other countries raises questions about their protection status. The typical question as to whether data undisclosed in one part of the world should be considered undisclosed in another part of the world remains unclear. Thus, if Company A discloses the data to the USFDA and then submits the same data in India after, say, four years, should India treat it as undisclosed, and if so, for how long? The ideal situation would be that if the drug regulator seeks information that is under protected status in another country, then it should be considered protected for the same length of time. ${ }^{92}$ Assume that after seeing Company A's application, a drug regulator in India wants particular clinical trial data from the United States that will enjoy two more years of protection in the United States; India should similarly protect the data for the remaining two years. Under the same logic, and considering that intellectual property laws are territorial in nature, any data voluntarily submitted in excess of what is required to approve the product in India need not be subject to such protection. Therefore, when data is reused in a second country, it may be subject to the laws and conditions of that country. Thus, the second country may extend the "undisclosed" status for the remaining term, taking the year of the first jurisdiction that applied protection into consideration. This view has been supported by academics like Carlos Correa and in other countries as well. ${ }^{93}$ The geographic flexibility remains important for all countries to carefully define the limits of the undisclosed term to balance with local healthcare needs.

92. See generally Armouti \& Nsour, supra note 41.

93. Carlos Correa, Unfair Competition Under the TRIPs Agreement: Protection of Data Submitted for the Registration of Pharmaceuticals, 3 CHI. J. INT'L L. 69, $72-73$ (2002); see also Armouti \& Nsour, supra note 41. 


\section{H. Should Exclusivity be Relaxed when National Markets are Not Being Supplied?}

"National markets not being supplied" is a ground for imposing a compulsory license under the TRIPS Agreement. ${ }^{94}$ Countries like India and Chile have statutorily included this as a ground for imposing compulsory licenses. ${ }^{95}$ When such a provision is effectuated to impose a compulsory license, similar to what happened when Bayer did not supply Nexavar in India, in the interest of the public, patents rights are suspended. ${ }^{96}$ Under those circumstances, the "public interest" exception outlined in Article 39 can be used to create statutory exceptions in national legislations to the use of the data for approving a competitor's application to supply the market. For example, under Chile's Industrial Property Law, pharmaceutical products not being marketed in the Chilean territory within 12 months from the registration or health authorization issued in Chile, or where the owner of the test data engages in conduct deemed contrary to free competition, are two specific exceptions to data exclusivity provisions (as well as over the patent monopoly) meant to provide access to healthcare. ${ }^{97}$

The United States does not follow the above prescription. Arguably, the United States embraces the most stringent data protection regime. In the Fabrazyme case, the National Institute of Health (NIH), dealing specifically with the question of refusing to exercise march-in rights, ${ }^{98}$ noted that the U.S. rules on test data exclusivity granted an absolute monopoly on the data that could not be waived even when the originator was unable to supply the U.S. market. ${ }^{99}$ This was in response to a patient group petition filed to the NIH on the grounds that the patent owner and its exclusive licensee harmed public health by severely rationing the supply of agalsidase beta, which is the only approved therapeutic treatment for Fabry disease. ${ }^{100}$

That said, the United States has come under pressure from the public. So far, the NIH has resisted using the march-in rights; but the rights exist under the Bayh-Dole Act. ${ }^{101}$ Recently, the NIH, regarding Xalatan, which

\footnotetext{
94. See TRIPS Agreement, supra note 8, at Art. 31.

95. See The Patents (Amendment) Act, 1970 (as amended in 2005) at $\S 84$ (India).

96. Bayer v. Natco M.P. Nos 74-76 of 2012 and M.P. No.108 of 2012 (India).

97. Industrial Property Law, supra note 50; see also FinK, supra note 50, at 394.

98. 35 U.S.C.S. § 203 (LexisNexis 2017).

99. See Test Data Protection for Medical Inventions, supra note 82.

100. See 2010 Fabrazyme March-in Request, KNOWLEDGe Ecology InT’L (Aug. 8, 2017), https://www.keionline.org/fabrazyme [https://perma.cc/SE83-NQMG].

101. 35 U.S.C.S. § 200 (LexisNexis 2018).
} 
is an expensive drug used for glaucoma treatment, ${ }^{102}$ defended its hesitancy to interfere using the march-in power to correct excessive pricing on the grounds that it could alter the market dynamics for all products developed pursuant to licensing rights under the Bayh-Dole Act. ${ }^{103}$ But, the NIH has clearly indicated that this is an area ripe for congressional consideration. ${ }^{104}$ Any congressional action to consider administrative, regulatory, or other forms of interference into the pricing of pharmaceuticals will have to deal with the question of data exclusivity over the clinical trials, although that may not happen anytime soon.

\section{Data Exclusivity \& Patent Linkage}

The last issue that relates to data exclusivity is patent linkage. The tying in of patent information with the data exclusivity is called patent linkage. ${ }^{105}$ Basically, when patent linkage is instituted, it would deem marketing approval of a competitor's product as a patent violation if there is patent protection over the application material. The question is whether TRIPS requires drug regulatory authorities to consider patent status before approving a generic substitute for marketability. Pharmaceutical companies assert that Article 39 of the TRIPS Agreement requires national governments to statutorily include patent linkage provisions. ${ }^{106}$ Such a patent linkage provision will essentially add an additional responsibility on the drug regulator and prevent them from clearing any competing versions of a drug for marketing if there is a patent prevailing on any similar version of the application material. ${ }^{107}$

The benefit of reading patent linkage into TRIPS is that typically, after the patent expires, the innovator will indirectly enjoy a market monopoly (market exclusivity as defined earlier in this Article) until the drug regulator clears the generic version which can be anywhere from two

102. Elias A. Zerhouni, Director, NIH, In the case of Xalatan, Manufactured by Pfizer, Inc. (Sept. 17, 2004), https://www.ott.nih.gov/sites/default/files/documents/policy/March-in-xalatan.pdf [https://perma.cc/9MME-ZWC8].

103. 35 U.S.C.S. § 200 (LexisNexis 2018).

104. See Zerhouni, supra note 102 ("[T] should be consistent across the spectrum of developing countries is one that would be more appropriately addressed by Congress, as it considered these matters in a larger context.”).

105. See id.

106. See, e.g., Bayer Corp. v. Union of India, Writ Petition No. No.7833 of 2008, Aug. 18, 2009; see also Bayer Corporation \& Anr v. Union of India \& Ors, Bayer Corp. v. Union of India, Writ Petition No.7833 of 2008, Aug. 18, 2009.

107. See Ravikant Bharadwaj, K.D. Raju \& M. Padmawati, The Impact of Patent Linkage on Marketing of Generic Drugs, 18 J. OF INTELL. PROP. RTS. 316-22 (2013), http://www.isglp.org/papers/india/ravikant/Ravikant\%20Bhardwaj\%20Publication\%20(3).pdf [https://perma.cc/XK5S-4PTU]. 
to four years after the expiration of patent protection. A study by the Federal Trade Commission highlighted that typically there is a 4- to 40month delay in the introduction of the generics when there is patent linkage. ${ }^{108}$ For poorer nations, imposing the linkage requirement will add one more regulatory layer involving additional cost and time. Patent linkage is a mechanism typically used to delay the entry of generic competition into the market.

Developed countries, especially the United States, assert that during the patent period, drug regulators should be prevented from approving a generic substitute. The United States unilaterally pressures other countries to include patent linkage provisions statutorily. ${ }^{109}$ In the United States, the history of patent linkage is unique. When the Hatch-Waxman Act ${ }^{110}$ was enacted, innovator pharmaceutical companies realized that they cannot deny generic drugs to the market anymore. Hence, patent linkage was proposed as an alternative to delay the entry of generic competition. ${ }^{111}$ Thus, when a generic drug company makes an application (ANDA application), the FDA will process the application only if there is no valid patent on the same. ${ }^{112}$ But, this has no international or universal relevance nor is this sound public health policy.

Canada, which tries to maintain a balance between innovator and generic pharmaceuticals, has a more nuanced approach wherein the Patented Medicines (Notice of Compliance) Regulations (NOC Regulations) ${ }^{113}$ provide for patent linkage. Under this, as part of seeking

108. Chuan-feng Wu, Raising the Right to Health Concerns within the Framework of International Intellectual Property Law, 5 Asian J. OF WTO \& INT'L HEALTH LAW \& POL'Y, 141, 141-205 (March 2010).

109. Id. In 2011 alone, about 16 countries, many of them developing, added patent linkage terms as part of its bilateral agreement with the United States. Id.

110. The Drug Price Competition and Patent Term Restoration Act of 1984, Publ. L. No. 98417, 1586-1605, (1984).

111. See, e.g., Ron A. Bouchard et al, Emphirical Analysis of Drug-Approval-Drug Patenting Linkage for High Value Pharmaceuticals, 2 Nw. J. OF TECH. \& INTELL. PROP. 174, 174-227 (2010) ("The linkage regulation regime in particular has proven to be an excellent vehicle for firms to obtain extended legal protection on drugs at all stages of development, including drugs about to come off patent protection, drugs moving through the regulatory approval stage, and drugs that are currently in development.").

112. See, e.g., Federal Food Drug \& Cosmetics Act, 21 U.S.C. § 301 505(j)(2)(A)(vii) (1938), which requires the ANDA applicant to state information, including the following: that such patent has expired (a paragraph II certification); the date on which such patent will expire (a paragraph III certification); or that such patent is invalid, unenforceable, or will not be infringed by the manufacture, use, or sale of the new drug for which the application is submitted (a paragraph IV certification).

113. The Patented Medicines (Notice of Compliance) Regulations, GOV’T OF CAN. (Oct. 27, 2016), https://www.canada.ca/en/health-canada/services/drugs-health-products/drug-products/ applications-submissions/guidance-documents/patented-medicines/notice-complianceregulations.html [https://perma.cc/KZ5P-XCSR]. 
marketing approval from Health Canada for a generic drug, the generic manufacturer is required to address the issues from any patents that the innovator may assert against it in a summary proceeding which can lead to either a patent validity or infringement litigation, under some circumstances. ${ }^{114}$

The question is not whether patent linkage is beneficial or not. In fact, countries that house innovator pharmaceutical companies will cater to patent linkage because it is in their best interest. Countries such as India (which predominantly houses a generic drug industry), and Brazil and Chile (which provide for universal health coverage) will be disadvantaged with patent linkage because it largely serves to delay generic drugs from entering into the market.

In India, marketing approval of drugs is not linked with the status of patents. The Indian position is that linking patent data with drug approval increases the burden of the generic drug company to prove the existence or otherwise of patents, and adds another layer of responsibility over the administrator. ${ }^{115}$ The question of whether Article 39 obligates members to establish patent linkage arose in India in relation to the approval of a generic version of "sorafenib tosylate," a drug used to treat renal cell cancer. ${ }^{116}$ The Supreme Court sustained the judgment of the Delhi High Court which dismissed the argument that patent linkage formed a part of the Article 39 obligation. Bayer, the patent owner, approached the Supreme Court of India to prevent the grant of marketing approval to Cipla. ${ }^{117}$ Bayer asserted that the TRIPS Agreement necessitated the establishment of patent linkage preventing the drug controller from approving the marketing of drugs whose patent was not owned by the applicant, Cipla. The Delhi High Court was persuaded by the presence of a Bolar Provision under Section 107A of the Indian Patents Act of 1970 which specifically exempted the use of data for regulatory processes from infringement with a view to permit immediate availability of generic

114. See generally Kristina Lybecker, Intellectual Property Rights \& Bio-pharmaceutical Industry: How Canada Measures Up, FRASIER INST. (Jan. 2017), https://www.fraserinstitute.org/ sites/default/files/intellectual-property-rights-protection-and-the\%20biopharmaceutical-industry.pdf [https://perma.cc/25XW-W5AZ].

115. See The Patents Act, No. 39 of $1970 \S 107(A)$; see also Srividhya Ragavan, Data Exclusivity: A Tool to Sustain Market Monopoly, 8 JindaL L. REV. 241, 241-60 (2017).

116. Bayer Corp. v. Union of India, Writ Petition No. No.7833 of 2008, Aug. 18, 2009; see also Bayer Corporation \& Anr v. Union of India \& Ors, Bayer Corp. v. Union of India, Writ Petition No.7833 of 2008, Aug. 18, 2009.

117. Bayer Corp. v. Union of India, Writ Petition No. No.7833 of 2008, Aug. 18, 2009; see also Bayer Corporation \& Anr v. Union of India \& Ors, Bayer Corp. v. Union of India, Writ Petition No.7833 of 2008, Aug. 18, 2009. 
drugs in the market when the patent expires. ${ }^{118}$ Nevertheless, that is an item that the United States has sought from India repeatedly under the Special 301 process on the grounds that Article 39 of TRIPS requires it. ${ }^{119}$

Chile's bilateral free trade agreement with the United States mandates patent-registration linkage and exclusive rights to pharmaceutical test data. ${ }^{120}$ Professor Carsten Fink notes that "Chile has implemented these obligations in a way that has sought to protect public health, promote coherence with patent rules, prevent anticompetitive behavior, and avoid imposing an undue burden on Chile's public health authority." ${ }^{121}$ Chile has a patent linkage requirement under Resolution 5572 which obligates the Institute of Public Health to publish all applications for health registration on its website. ${ }^{122}$ The information on regulatory approvals are electronically posted to enable patent holders to monitor regulatory requests and seek an injunction from a Chilean court to prevent issuing the marketing approval if the patent holder believes that a pharmaceutical application for which a regulatory approval to market is sought infringes on a patent. ${ }^{123}$

Importantly, Article 39 of TRIPS is certainly not worded to impose patent linkage. ${ }^{124}$ Even assuming that it was the case, such a reading of Article 39.3 will not survive the Doha Declaration on Public Health. ${ }^{125}$ Data exclusivity and patent linkage also affects the operation of compulsory licenses. ${ }^{126}$ Otherwise, even when there is a public health

118. The Patents Act, supra note 115.

119. See, e.g., Srividhya Ragavan, Sean Flynn \& Brook Baker, Justifying India's Patent Position to the United States International Trade Commission and Office of the United States Trade Representative, 7 INDIAN J. INTELL. PROP. LAW 1 (2015) (discussing the unilateral U.S. pressure on India to amend its patent laws in a manner not conducive to provide access to health-care for its poorer citizens).

120. Chile-United States Free Trade Agreement (signed June 6, 2003), https://ustr.gov/sites/default/files/uploads/agreements/fta/chile/asset_upload_file535_3989.pdf [https://perma.cc/NB3Q-28ED].

121. FinK, supra note 50, at 394; see also Chile-United States Free Trade Agreement (signed June 6, 2003), https://ustr.gov/sites/default/files/uploads/agreements/fta/chile/ asset_upload_file535_3989.pdf [https://perma.cc/NB3Q-28ED].

122. Industrial Property Law, supra note 50; Law No. 19.039, Revised, Coordinated and Systemized Text of The Industrial Property Law, Resolution 5572 of the Chilean Institute of Public Health, Mar. 9, 2006, Ministry of Economy [BCN] (Chile), http://www.wipo.int/wipolex/ en/details.jsp?id=5324 [https://perma.cc/LK7R-ZUXQ] (providing overview of enactment of patent linkage requirements and amending Chilean Law No. 19.039 on Industrial Property, further containing a link to Resolution 5572 itself).

123. See also FINK, supra note 50, at 394.

124. See, e.g., id. at 391 (“The TRIPS Agreement does not impose any obligation of this kind.”).

125. World Trade Organization, Ministerial Declaration of 14 November 2001, WTO Doc. WT/MIN(01)/DEC/1, 41 ILM 746, ๆ 17 (2002).

126. See, e.g., Industrial Property Law, supra note 50. 
crisis, the presence of patent linkage can prevent a regulator from approving the drug that may be needed to preserve public health conditions. Thus, any reading of Article 39 of TRIPS to impose patent linkage requirements will be read as violating the Doha Declaration on Public Health. ${ }^{127}$

\section{CONCLUSION}

The access to medication questions have become a burden that TRIPS continues to bear poorly. As patents and the cost of drug prices have become increasingly unpopular, ${ }^{128}$ data exclusivity has morphed into a more potent tool benefitting from vigorous focus from pharmaceutical lobbying groups. ${ }^{129}$ The unfortunate development seems to be that data exclusivity is quickly becoming a hurdle to public health. Notably, the public has a vested interest when any form of exclusivity is legally created, especially when it prevents or detrimentally affects access to life saving medication.

Considering this, it is critical for developing countries to determine the extent of protection and to effectively use the public interest exception of Article 39.3. It is acknowledged that data exclusivity as a tool detrimentally affects generic competition. ${ }^{130}$ Thus, it is no coincidence that developing countries and free trade partners have been pressured by the United States Trade Representative to further extend data protection. ${ }^{131}$ Whether it be data exclusivity provisions or other TRIPS-

127. Id.

128. Ghinea et.al., supra note 44; see also Ayalew Tefferi et al., In Support of a Patient-Driven Initiative and Petition to Lower the High Price of Cancer Drugs, MAYO ClinIC PROC. 996 (Aug. 2015), http://dx.doi.org/10.1016/j.mayocp.2015.06.001 [https://perma.cc/M4PL-BCZ4]; see also Donald Light \& Hagop Kantarjian, Market Spiral Pricing of Cancer Drugs, CANCER, 3900 (Nov. 2013), http://onlinelibrary.wiley.com/doi/10.1002/cncr.28321/epdf [https://perma.cc/9TVLRNUW]; see generally Brian Godman et al., Patent Expiry and Costs for Anti-cancer Medicines for Clinical Use: Expiry and Costs Anti-cancer Medicines, 6 GENERICS AND BIOSIMILARS INITIATIVE J. (GABI J.) 105 (2017), https://strathprints.strath.ac.uk/60241/ [https://perma.cc/M7SR-5XXW].

129. See, e.g., Ragavan, Data Exclusivity, supra note 115; see also Srividhya Ragavan, The Significance of the Data Exclusivity and its Impact on Generic Drugs, 1 J. INTELL. PROP. STUD. 131, 134-37 (2017).

130. See Xavier Seuba, Pharmaceutical Test Data Protection \& Human Rights, P. K. Yu, (Ed.), Reshaping Intellectual Property Law through a Human Rights Lens, Cambridge University Press, 2017 (extensively discussing access to medication issues from data exclusivity).

131. The much higher standard of data exclusivity sought under the now-failed Trans-Pacific Partnership is a great example. See Lybecker, When Patents Aren't Enough, supra note 12; see generally What does the TPP say About Data Exclusivity and Biosimilars?, MANAGED CARE, https://www.managedcaremag.com/focus/what-does-tpp-say-about-data-exclusivity-and-biosimilars [https://perma.cc/K8FA-ZHYH] (last visited Mar. 7, 2018). Similarly, in trade negotiations, and in 
plus requirements to patent statutes, developing countries should appreciate that such compromises need not be emulated in every market, especially in countries that have a policy focus on enabling access to medication. ${ }^{132}$ In reality, for developing countries, generics have become a part of the global pharmaceutical industry. In fact, globally, generic drugs have become a necessary component of the pharmaceutical food chain, not only to cater to the access to health needs, but also to kick start innovation in poorer nations. It is also undisputed that historically, copying has been the first step for innovation even in the developed world.

Thus, for innovation in pharmaceuticals to proliferate all over the world, generics will serve as the first step to kick start the industry. Especially for less-developed countries, the leap to innovation in pharmaceuticals will occur only when they take the first step of being able to establish generic drug manufacturing facilities locally. Further, even in developed nations where there is much patent fetish, such as the United States, the astronomical cost of medication has resulted in an increased appreciation for the role of generics. Thus, generics are viewed as an important component to enable market competition, to challenge bad patents, and to provide access to medication. Developing countries such as India and Brazil should not back pedal into limiting the generic manufacturers without having a clear roadmap to provide alternative access to medication, which it lacks now.

Free Trade Agreements with other countries, the United States tends to prefer definitions that interpret Article 39 more stringently in a manner requiring a much higher data protection requirement.

132. See Maria Phelan \& Catherine Cook, A Treatment Revolution for Those Who can Afford it? Hepatitis C Treatment: New Medications, Profits and Patients, BMC INFECTIOUS DISEASES (2014), https://www.ncbi.nlm.nih.gov/pmc/articles/PMC4178584/ [https://perma.cc/HCF5-RFPS] (discussing how the company allowed some countries to make these new medicines available at cost for their populations or appreciable discounts); see also Winnie de Bruijn et al., Introduction and Utilization of High Priced HCV Medicines across Europe; Implications for the Future, 7 FrONTIERS IN PHARMACOlOGY (2016), https://www.ncbi.nlm.nih.gov/pubmed/27516740 [https://perma.cc/V38K-Q8J8]; see also Srividhya Ragavan, Patients Win Over Patents, THE HINDU (Mar. 7, 2013), http://www.thehindu.com/opinion/op-ed/patients-win-overpatents/article4482469.ece [https://perma.cc/SLZ6-D7XS]; see generally, Ragavan \& Dave, The Right Prescription to the IPR Debate, Hindustan Times, (Sept. 29, 2014), http://www.hindustantimes.com/ht-view/the-right-prescription-in-the-ipr-debate/storyaEvB8EGLIsoweSdpozDwBI.html [https://perma.cc/5PNN-SVA9]. 